\title{
Evaluation and Selection of Some Date Palm Seedlings (Phoenix dactylifera L.) Growing under Sohag Region Conditions.
}

\author{
A. O. Rayan \\ Fruit and Ornamental Breeding Department, Horticultural \\ Research Institute, Agricultural Research Centre, Cairo, Egypt.
}

\begin{abstract}
7 HIS STUDY was conducted to evaluate ten seedlings of Date palm (R) (Phoenix dactylifera $\mathrm{L}$.) to select the highest yield and fruit quality of the unknown semi-dry seedlings trees growing under the conditions of Sohag region, Egypt, in comparison with the commercial cv. Seewy during two successive seasons (2011 and 2012). Data of yield per palm ( $\mathrm{kg})$ as well as physical and chemical properties of fruit were recorded. The results revealed that; Highest yield was obtained from $\mathrm{R}_{3}(127.55 \mathrm{~kg} / \mathrm{palm})$ in comparison with other tested, as well as Seewy cv. which produced lowest yield (101.11 $\mathrm{kg} / \mathrm{palm}$ ). Concerning physical properties, $\mathrm{R}_{3}$ showed that the highest values of physical properties fruit diameter $2.83 \mathrm{~cm}$, fruit length $5.06 \mathrm{~cm}$, pulp thickness $0.92 \mathrm{~cm}$, fruit weight $19.44 \mathrm{~g}$., Seed weight $1.59 \mathrm{~g}$., pulp weight $85.31 \%$ in comparison with other tested and Seewy cv. was $2.07,4.45,0.81,17.19,1.58,78.86$ respectively. As for chemical properties, $\mathrm{R}_{3}$ developed the highest values of T.S.S $41.62 \%$, total acidity $1.52 \%$, total sugars content $83.67 \%$, reducing sugars content $44.05 \%$, non-Reducing sugars content $39.62 \%$. the seedlings $\left(\mathrm{R}_{3}\right)$ had lower tannins content $1.74 \%$, while the highest tannins percentage was recorded for $\mathrm{R}_{5}, 6,7$ was $1.86 \%$ in comparison with other tested palms as well as Seewy cv. T.S.S $39.64 \%$, total acidity $1.58 \%$, total sugar content $71.96 \%$, reducing sugars content $37.00 \%$, non-Reducing sugars content $30.16 \%$, tannins $1.82 \%$ respectively.
\end{abstract}

General evaluation revealed that $R_{3}$ date palm seedlings provide to be the superior in yield and fruit quality among all the studied trees.

Keywords: Evaluation, Date palm seedlings, Yield, Fruit quality.

Date palm (phoenix dectylifera L.) is one of the most important fruit crop in Egypt. According to F.A.O. (2009), the number of fruitful female palms was about 12 million, producing about 1270478 tons of fruits.

Egypt is considered to be one of the major date producing countries in the world. Date palm is grown in Egypt in both Nile Valley and desert districts. About two hundred different date cultivar are known, of these only a few have been so for investigated for their physical and chemical characteristics (Ragab 
et al., 1956, Selim et al., 1968, Abd-El-Rahman 1974, Mousa, 1981 \& 1985, Hussein et al., 1984 and Abdullah \& Nady, 2009).

Date palm cultivars divided into three main groups according to its fruit moisture content, I.e. Soft. Semi - dry and dry cultivars. Date palm is the national crop in Sohag, Egypt has been widely planted in the country for a long time and so there are many valuable genetic resources. The selection of fruit trees is considered one of the important methods for improving fruit cultivars (Rokba et al., 1990).

The production of the date palms by seeds is considered an easy and cheap way of propagation. As a result of the sexual reproduction some of the seedling date palms are highly desirable for fruit quality.

The present investigation was aimed to survey and select the high fruit quality of unknown date palm seedlings, grown under the conditions of Sohag region.

\section{Material and Methods}

This study was carried out at Sohag governorate in two successive seasons (2011 and 2012). To evaluate ten of seedlings clones of date palm $\left(R_{1}, R_{2}, R_{3}, R_{4}\right.$, $\mathrm{R}_{5}, \mathrm{R}_{6}, \mathrm{R}_{7}, \mathrm{R}_{8}, \mathrm{R}_{9}$ and $\mathrm{R}_{10}$ ) about 15 years old grown at Sohag governorate. The experimental palms were healthy, nearly uniform in growth, vigor, height and fruiting capacity in the preceding years. The trees were subjected to the normal cultural practices. The total number of surveyed date palm seedling reached fifty seedlings trees. The chosen palms are of semi-dry date fruits. The chosen ten seedlings trees were evaluated, for the following indices were studied and recorded: yield per palm, physical and chemical fruits characters. Seewy cv. standard for semi-dry date palm fruits was also studied.

The following parameters were studied and recorded:

\section{Yield components}

Yield per palm $(\mathrm{kg})$

Fruit physical properties

- Samples of 100 fruits /palm were taken at random for the following determinations:

- 2.1-Fruit diameter $(\mathrm{cm})$

- 2.2-Fruit length $(\mathrm{cm})$

- 2.3-pulp thickness $(\mathrm{cm})$

- 2.4-Fruit weight (g.)

- 2.5-Seed weight (g.)

- 4.6-pulp weight $\%$

Fruit chemical properties

Juice was used for determination of T.S.S. percentage as g/ 100g F.wt. Using hand refractometer according to Chen and Mellenthin (1981).

Egypt. J. Hort. Vol. 41, No.1 (2014) 
Total acidity percentage (expressed as g. malic acid/100g. pulp) was determined (A.O.A.C., 1985).

Sugars (total) and reducing sugar content were determined according to Lane and Eynon proceduse as pointed out in (A.O.A.C., 1985).

Tannins content was determined using procedure made by A.O.A.C. (1970). The final evaluation of any tested tree fruit was calculated on the basis of 100 units which were shared between palm yield (50 units) and fruit quality (50 units) Hussein et al. (1982). The latter units were divided on the basis of 10 units for each of fruit weight, pulp \%, T.S.S and total sugars percent and 5 units for the percent of both acidity and tannins. Each palm that had the best results in any character took the full mark specified for this character, while each of the other tested palms took lower units equal to their quality. For instance if palm no. 3 produced the highest yield it will be given all the 50 units specified for this character accordingly by units of any other tested palm for the same character could be calculated as follows:

$$
\frac{\text { yield per palm of tested palm X50 }}{\text { yield of palm no. } 3}
$$

Similarly, units for any concerned character were calculated in the same way.

\section{Statistical analyses}

The obtained data during the study were statistically analyzed by the randomized complete design. Using the MSTAT-C (1990) software for comparison of the mean values by L.S.D. test at the 0.05 level response equations were calculated according to (Snedecor and Cochran, 1988).

\section{Yield components}

\section{Results and Discussions}

From data of yield per palm given in Table 1 it is appeared that highest yield was Obtaned by $R_{3}$ date palm seedlings $(127.55 \mathrm{~kg})$ followed in a descending order the average yield $(116.39,115.54,114.37,113.82,113.10,111.73,111.42$, $109.98,109.72 \mathrm{~kg}$, for $\mathrm{R}_{1}$, R8, R4, R5, R2, R10, R9, R7, R6 respectively) compared to Seewy cv average $(101.11 \mathrm{~kg}$ ) of the two seasons. The results are in agreement with those reported by Mousa (1981), Moustafa et al. (1986) Salem \& Hamdy (1993), Ahmed et al. (1996) and Abdullah \& Nady (2009).

\section{Fruit characteristics}

Physical fruit properties

Results in Table 1 indicated significant differences in fruit diameter, fruit length, pulp thickness, fruit weight, seed weight, pulp weight in two seasons between the tested verities and Sewy cv. 


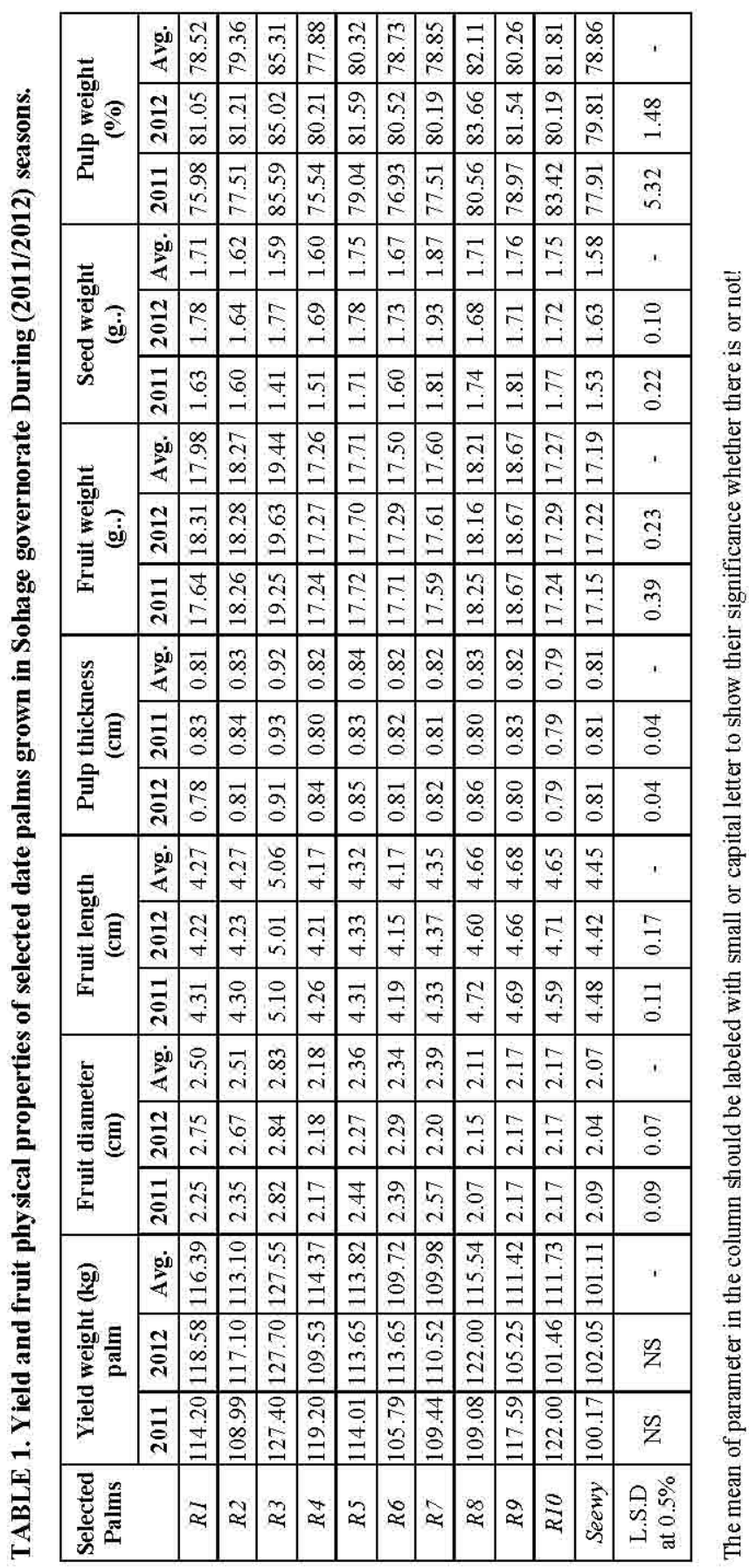




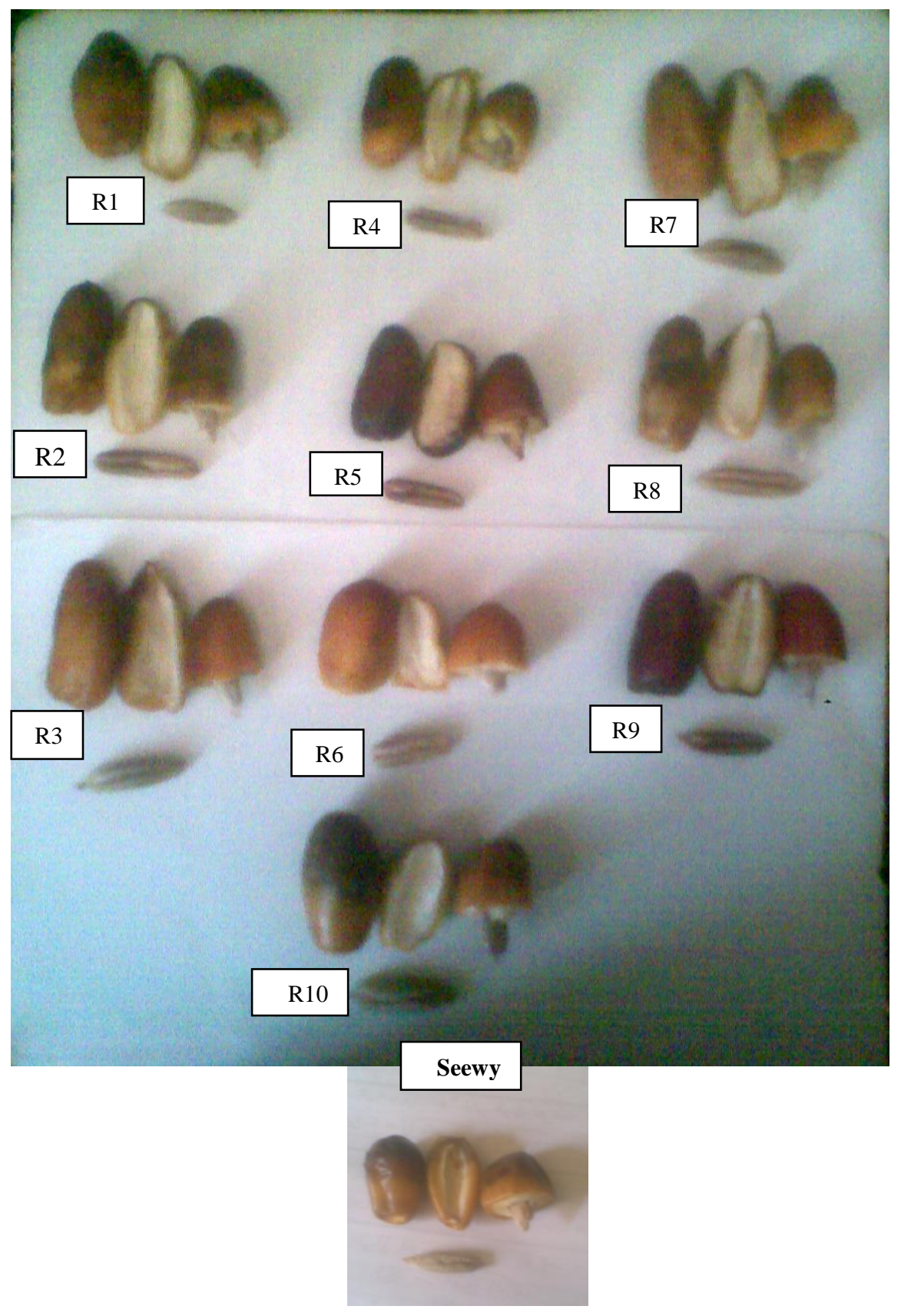

Fig. 1. The morphological charactarestics for ten date palm seedling tree . 
The average values for the two seasons show that fruit diameter was highest in $R_{3}$ date palm seedlings $(2.83 \mathrm{~cm})$ followed in a descending order by $R_{2} 2.51, R_{1}$ 2.50, $\mathrm{R}_{7} 2.39, \mathrm{R}_{5} 2.36, \mathrm{R}_{6} 2.34, \mathrm{R}_{4} 2.18, \mathrm{R}_{10} 2.17, \mathrm{R}_{9} 2.17$ and Seewy cv $2.07 \mathrm{~cm}$. $\mathrm{R}_{3}$ fruit length gave $(5.06 \mathrm{~cm})$ followed in a descending order by $R_{9} 4.68, R_{8}$ 4.66, $\mathrm{R}_{10} 4.65, \mathrm{R}_{7} 4.35, \mathrm{R}_{5} 4.32, \mathrm{R}_{2} 4.27, \mathrm{R}_{1} 4.27, \mathrm{R}_{4} 4.17, \mathrm{R}_{6} 4.17$ and Seewy cv. was $4.45 \mathrm{~cm}$.

On the other hand pulp thickness of (R3) date palm seedling $(0.92 \mathrm{~cm})$ followed in ascending order by $\mathrm{R}_{10} 0.79, \mathrm{R}_{1} 0.81, \mathrm{R}_{4} 0.82, \mathrm{R}_{6} 0.82, \mathrm{R}_{7} 0.82, \mathrm{R}_{9}$ $0.82, R_{8} 0.83, R_{2} 0.83, R_{5} .0 .84 \mathrm{~cm}$ as compared to Seewy cv. average $(0.81 \mathrm{~cm})$. Selim et al. (1968), Abdalla (1980) and Abo Rekab and El-Kerdany (2008), found that pulp thickness varies according to cultivar. The data also reveal that fruit weight was highest in $\mathrm{R} 3$ date palm seedling (19.44 g.), followed in descending order by $\mathrm{R}_{9} 18.67, \mathrm{R}_{2} 18.27, \mathrm{R}_{8} 18.21, \mathrm{R}_{1}$ 17.98, $\mathrm{R}_{5}$ 17.71, $\mathrm{R}_{7}$ 17.60, $\mathrm{R}_{6} 17.50, \mathrm{R}_{10} 17.27$ and $\mathrm{R}_{4} 17.26$, as compared to Seewy cv. $17.19 \mathrm{~g}$.

The data also showed that seed weight in $\mathrm{R} 3$ average in the two seasons was $1.59 \mathrm{~g}$. followed in ascending order by $\mathrm{R}_{9} 1.76, \mathrm{R}_{6} 1.67, \mathrm{R}_{10} 1.75, \mathrm{R}_{5} 1.75, \mathrm{R}_{1}$ $1.71, \mathrm{R}_{8} 1.71, \mathrm{R}_{2} 1.62, \mathrm{R}_{4} 1.60$, and $\mathrm{R}_{7} 1.87 \mathrm{~g}$. as compared to Seewy cv. $1.58 \mathrm{~g}$. The pulp weight average $85.31 \%$ in $\left(R_{3}\right)$ followed by $R_{8} 82.11, R_{10} 81.81, R_{5}$ 80.32, $\mathrm{R}_{9}$ 80.26, $\mathrm{R}_{2} 79.36, \mathrm{R}_{7} 78.85, \mathrm{R}_{6} 78.73, \mathrm{R}_{1} 78.52$ and $\mathrm{R}_{4} 77.88 \%$ as compared to Seewy cv. was average $78.86 \%$. These findings are in harmony with those obtained by Hussin et al. (1975), Salem \& Hamdy (1993), Ahmed et al. (1996), Said-Shren (1999) and Abdullah \& Nady (2009).

\section{Chemical fruit properties}

Chemical constituents of fruits. i.e. Total soluble solids (T.S.S), total acidity, total sugars content, reducing sugars content, non-Reducing sugars content and tannins for semi dry date palm seedlings as well as Seewy cv cultivar are presented in Table 2. Total soluble solids date palm seedlings $R_{3}$ is higher significant by (41.62\%) followed in a descending order by $R_{7} 40.59, R_{6} 40.50$, $\mathrm{R}_{4} 40.41, \mathrm{R}_{5} 40.31, \mathrm{R}_{1} 40.18, \mathrm{R}_{2} 40.00, \mathrm{R}_{10} 39.86, \mathrm{R}_{9} 39.84, \mathrm{R}_{8} 39.74$ and as compared with Seewy c.v (39.64\%).

Data also reveal that the lowest value for total acidity $1.52 \%$ was found in fruit palm $\mathrm{R}_{3}$ followed by $\mathrm{R}_{2} 1.62, \mathrm{R}_{1} 1.61, \mathrm{R}_{9} 1.61, \mathrm{R}_{6} 1.60, \mathrm{R}_{8} 1.60, \mathrm{R}_{10} 1.60, \mathrm{R}_{5}$ $1.59, \mathrm{R}_{7} 1.59$ and $\mathrm{R}_{4} 1.58$ compared with Seewy cv was $1.58 \%$.

The total sugars was $83.67 \%$ in fruit palm $\mathrm{R}_{3}$ followed by $78.31,77.38$, 77.25, 77.18, 77.15, 75.65, 75.36, 75.20, 75.00 for palms $R_{10}, R_{8}, R_{1}, R_{9}, R_{4}, R_{7}$, $\mathrm{R}_{2}, \mathrm{R}_{6}, \mathrm{R}_{5}$, respectively. However Seewy fruits recorded $71.96 \%$ in this respect. Hussien and Samiraea (1976) reported that total sugars content in Barhi dates was $83.19 \%$ (on dry weight basis). Sourial et al. (1983) found that total sugars content of Hallawy, sayer and Barhi fruits were 31.28, 26.68 and 24.95\%, respectively (fresh weight basis). 


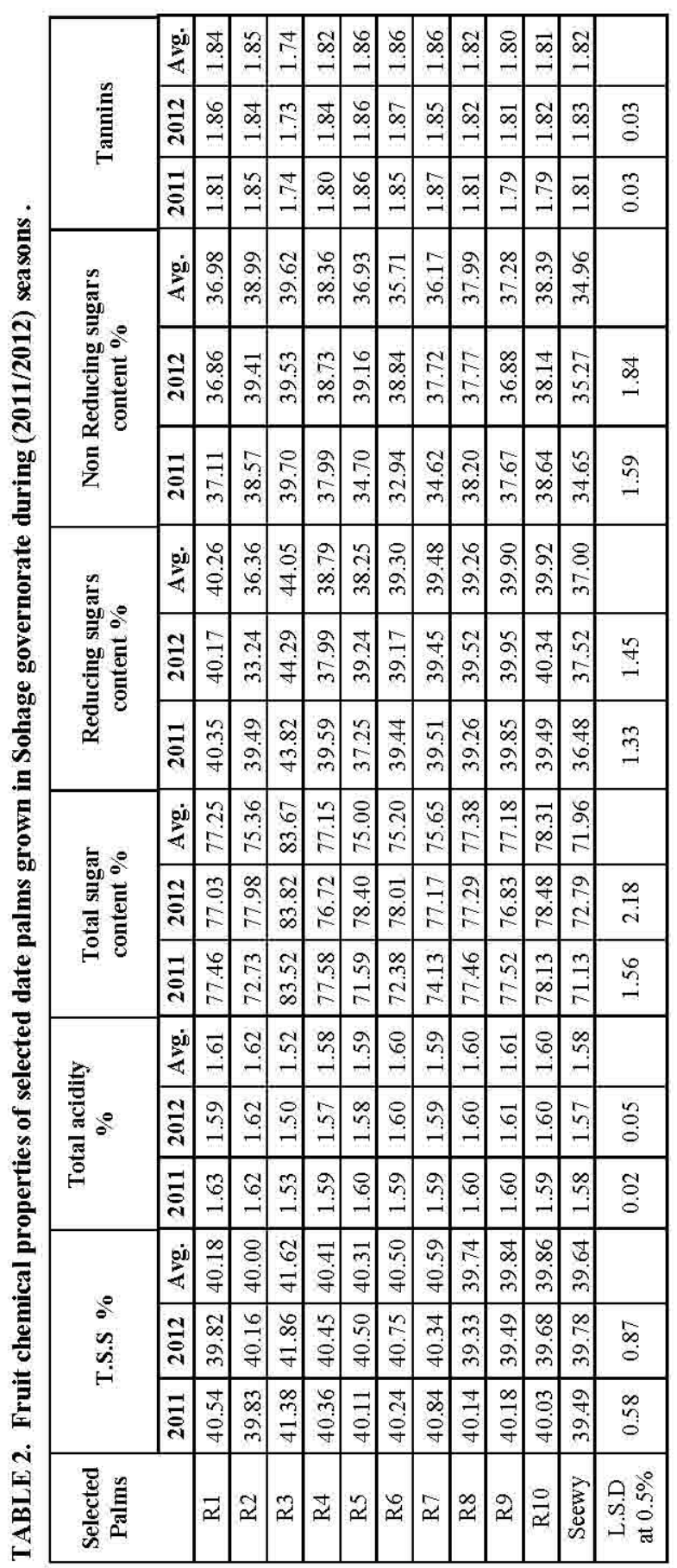

Egypt. J. Hort. Vol. 41, No.1 (2014) 
Data also showed that the highest values for reducing sugars was $44.05 \%$ in fruit palm R3 followed by 40.26, 39.92, 39.90, 39.48, 36.36, , 39.30, 39.26, $38.79,38.25$ and $36.36 \%$ for Palms $\mathrm{R}_{1}, \mathrm{R}_{10}, \mathrm{R}_{9}, \mathrm{R}_{7}, \mathrm{R}_{2}, \mathrm{R}_{6}, \mathrm{R}_{8}, \mathrm{R}_{4}, \mathrm{R}_{5}$ and $\mathrm{R}_{2}$ respectively, however Seewy cv recorded $37.00 \%$. Similar results were reported by Salem \& Hamdy (1993) and Abo Rekab \& El-Kerdany (2008).

As shown in Table 2 non reducing sugars showed the highest values (39.62\%) in fruit of palm $\mathrm{R}_{3}$ followed by $38.99,38.39$, 38.36, 37.99, 37.28, 36.98, 36.93, 36.17 and $35.71 \%$ for palms $\mathrm{R}_{2}, \mathrm{R}_{10}, \mathrm{R}_{4}, \mathrm{R}_{8}, \mathrm{R}_{9}, \mathrm{R}_{1}, \mathrm{R}_{5}, \mathrm{R}_{7}$, and $\mathrm{R}_{6}$ respectively, compared to Seewy cv recorded $37.00 \%$. These results are similar to Sourial et al. (1983), Salem \& Hamdy (1993) and Abo Rekab \& El-Kerdany (2008).

Data recorded that fruits of $\mathrm{R}_{3}$ had lower tannins average (1.74\%) followed by $_{9} 1.80, \mathrm{R}_{10} 1.81, \mathrm{R}_{8} 1.82, \mathrm{R}_{4} 1.82$ compared with Seewy cv the highest tannins was recorded (1.82\%). On the other hand fruit of $R_{1} 1.84 R_{2} 1.85 R_{5} 1.86$, R6 1.86 and $\mathrm{R}_{7} 1.86$ as highest tannins similar results reported by Ragab et al. (1956), Bondok (1975) and Abdalla \& Nady (2009).

\section{General evaluation and final conclusion}

Data tabulated in Table 3 show that palm no. 3 seemed to be the superior type in yield and fruit quality among all the tested palms, as it attained the uppermost score units (100.00) as compared with the "Seewy cv." (85.24).

On the contrary, thus one can conclude that all 3 selected palms are in a good fruit quality for consumer but only palm 3 showed the highest yield.

TABLE 3. Evaluation values of crop, physical and chemical fruit properties at harvest for selected date palms grown in Sohage governorate during (2011 and 2012) seasons

\begin{tabular}{|c|c|c|c|c|c|c|c|c|}
\hline $\begin{array}{c}\text { Selected } \\
\text { palms }\end{array}$ & $\begin{array}{c}\text { Yield } \\
\mathbf{5 0} \\
\text { unite }\end{array}$ & $\begin{array}{c}\text { Fruit } \\
\text { weight } \\
\mathbf{1 0} \\
\text { unite }\end{array}$ & $\begin{array}{c}\text { Pulp } \\
\text { weight } \\
\mathbf{1 0} \\
\text { unite }\end{array}$ & $\begin{array}{c}\text { T.S. S } \\
\mathbf{1 0} \\
\text { unite }\end{array}$ & $\begin{array}{c}\text { Total } \\
\text { sugars } \\
\mathbf{1 0} \\
\text { unite }\end{array}$ & $\begin{array}{c}\text { Tetratable } \\
\text { acidity 5 } \\
\text { unite }\end{array}$ & $\begin{array}{c}\text { Tannins } \\
\mathbf{1 0} \text { unite }\end{array}$ & $\begin{array}{c}\text { Total } \\
\mathbf{1 0 0} \\
\text { unite }\end{array}$ \\
\hline R1 & 45.62 & 9.25 & 9.20 & 9.65 & 9.23 & 4.72 & 4.71 & 92.38 \\
\hline R2 & 44.35 & 9.40 & 9.30 & 9.61 & 9.00 & 4.77 & 4.69 & 91.12 \\
\hline R3 & 50.00 & 10.00 & 10.00 & 10.00 & 10.00 & 5.00 & 5.00 & 100.00 \\
\hline R4 & 44.83 & 8.88 & 9.13 & 9.71 & 9.22 & 4.80 & 4.77 & 91.34 \\
\hline R5 & 44.61 & 9.11 & 9.42 & 9.69 & 8.96 & 4.77 & 4.66 & 91.22 \\
\hline R6 & 43.01 & 9.00 & 9.23 & 9.73 & 8.99 & 4.74 & 4.66 & 89.36 \\
\hline R7 & 43.11 & 9.05 & 9.21 & 9.75 & 9.04 & 4.77 & 4.66 & 89.59 \\
\hline R8 & 45.29 & 9.37 & 9.62 & 9.55 & 9.25 & 4.74 & 4.77 & 92.59 \\
\hline R9 & 43.68 & 9.60 & 9.41 & 9.57 & 9.22 & 4.70 & 4.83 & 91.01 \\
\hline R10 & 43.80 & 8.88 & 9.59 & 9.58 & 9.36 & 4.74 & 4.80 & 90.75 \\
\hline Seewy & 39.64 & 8.84 & 9.24 & 9.52 & 8.60 & 4.80 & 4.78 & 85.24 \\
\hline
\end{tabular}

\section{Conclusion}

Data in Tables 1, 2 and 3 show that date palm seedlings (3) seemed to be the superior one in yield and fruit quality among all the tested palms Thus one can

Egypt. J. Hort. Vol. 41, No.1 (2014) 
conclude that all 10 selected palms are of a good fruit quality for consumer but only palm $R_{3}$ showed the highest yield. The evaluation of this new strain will give good chance for breeders and fruit growers to produce new cultivar.

\section{References}

Abdalla, M.Y. (1980) Studies on some soft date cultivars. M. Sc. Thesis, Fac. Agric., Zagazig. Univ., Egypt.

Abdalla, M.Y., Bastawros, M.B. and Haggag, L.F. (1991) Effect of plantation zone on bunch and fruit properties of Samany date. Zagazig J. Agric. Res., 18 (1),135-143.

Abd-El-Rahman, M.H. (1974) Studies on physiological and physical changes in the fruit of some date verities after maturity. M. Sc.Thesis, Fac, Agric., Cairo Univ. Egypt.

Abdullah A.S. and Nady, N.H. (2009) Evaluation of thirteen seedling date palms grown in Aswan governorate, Egypt J. Agric. Sc Mansoura Univ. 34 (5), 6707-6714.

Abo Rekab, Zeinab, A.M. and El-Kerdany, A.Y. (2008) Evaluation of date palm seedlings grown in EL-Fayoum governorate. Egypt. J. Appl. Sci., 23 (12B).

Ahmed, F.F., El-Malt, E.A., Ragab, M.A. and Ahmed, A.A. (1996) Comparative study of productivity, some physical, chemical and nutritional characteristics of thirteen Saudian and Iraqi date palm cultivars. Annals of Agric. Sci. Moshtohor, 34 (4),18091833.

Association of Official Agricultural Chemists (1985) Official Methods of Analysis (A.O.A.C.), $12^{\text {th }}$ ed., published by A.O.A.C, Benjamin Franklin Station, Washington D.C., USA, pp. 490-510.

Association of Official Analytical Chemists (1970) "Official Method of Analysis", $11^{\text {th }}$ ed., Washington, D.C., p. 240

Bondok, A. Z. (1975) Physiological studies on artificial ripening of some date fruits Ph.D. Thesis, Fac. Agric., Ain Shams Univ., Cairo.

Chen, P.M. and Mellenthin, W.M. (1981) Effect of harvest date on ripening capacity and post harvest life of d'Anjo pears. J. Amer. So. Hort. Sci., 106(1), 38-42.

F.A.O. (Food and Agriculture Organization), the statistical year book (2009) www.Fao.orf/economic/statistical/yearbook/FAO/2009.

Hussein, A.A., Gamal, N.M., Nour, G.M. and Habib, S.S. (1984) Evaluation of some date Palme verities grown in South Sinai governorate, Aric. Res. Rev., 62 (3A) 289303.

Hussein, F. and El-Samiraea, F. (1976) Studies on physical and chemical characteristics of eighteen date cultivars grown in Saudi Arabia. Indian J. Hort., 33.

Hussein, F., Dahshan, D. I., Gaafar, S. I. and Mousa, I. A. (1982) Evaluation of some date palms grown at Ismailia governorate. Fac. Agric., Zagazig Univ., Res. Bull., No. 506. 
Hussin, F.M., El-Samiraea, S. and El-Zeid, A. (1975) Studies on physical and chemical characteristics of eighteen date cultivars grown in Soudia Arabia. Indian J., $\mathbf{3}$ (2), 107 .

Mousa, I. A. (1981) Evaluation and studies of some seedling date palm grown at Ismailia Province. M. Sc. Thesis, Fac. Agric., Zagazig Univ.

Mousa, I. A. (1985) Studies and evaluation of some local date cultivars grown at Sharkia governorate. Ph.D. Thesis, Fac. Agric. Zagazig Uni. Egypt.

Moustafa, A.A., El-Aidy, A.A. and El-Sammak, A.P. (1986) Evaluation and study of some seedling date palms grown at El-Wady El-Gedid. Second symposium on date palm. March 3-6, King Fisal Univ., Saudi Arabia, pp.153-161.

MSTAT-C. (1990) Microcomputer statistical program for experiment design and analysis. MSTAT / Michigan State University, Michigan, USA.

Ragab, M.H.H., El-Tobey Shehata, A.M. and Sedky, A. (1956) Studies on the Egyptian dates. 2-chimical changes during development and ripening of six varieties. Food Tech., 10, 407-410.

Rokba, A.M., Seif, S.A. and Abou El-Azayem, A.I. (1990) Biological studies on some date palm seedling grown in Fayoum governorate. J. Agric. Sci. Mansoura Univ., 15 (2), 232-238.

Said-Shren, M. (1999) Evaluation of some date Palm cultivars El-Minia region condition M.Sc. Thesis, Fac. Agric. Minia Univ. Egypt.

Salem, M.S. and Hamdy, Z.M. (1993) Fruit quality and general evaluation of some Iraqi date palm cultivars grown under conditions of Upper Egypt. Egypt Journal of Applied Science, 8(5), 250-269.

Selim, H.A., El-Mahdi, M.A.M. and El-Hakeem, M.S. (1968) Studies on the evaluation of 15 local date varieties grown under desert condition in Siwa Oasis, UAR. Bull. De l'institut du Desert d'egypt, T. XVIII, No.1.

Snedecor, G.E. and Cochran, W.G. (1988) Statistical Methods, $7^{\text {th }}$ ed. Iowa State Univ. Press. Ames, Iowa, USA.

Sourial, G.F., Meligi, M.A., Mohsen, A.M., Khalifa, A. and Abdalla, M.Y. (1983) Fruit quality and general evaluation of some Iraqi date palm cultivars grown under conditions of Barrage region, Egypt. Proc. The first symposium on date palm in Saudi Arabia, March 23-25. 
EVALUATION AND SELECTION OF SOME DATE PALM SEEDLINGS ... 107

تقييم وانتخاب لبعض سلالات النخيل البذريه تحت ظروف محافظة

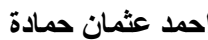

قسم بحوث تربية الفاكهة - معهل بحوث البساتين - مركز البحوث الزراعية -

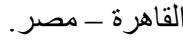

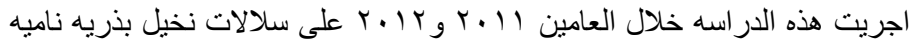

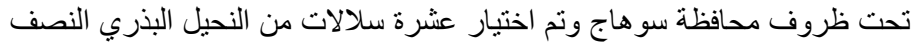

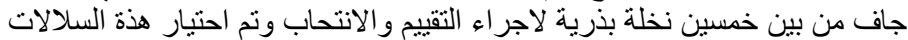

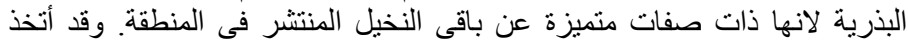
الصنف السيوي المنتشر في المنطقة كأساس للمقارنة وأظهر التقييم العام.

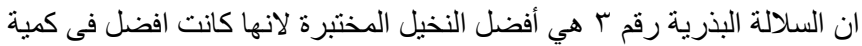

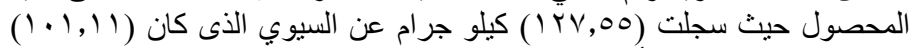

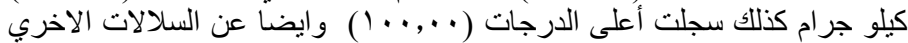

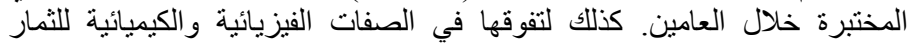

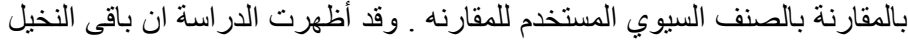

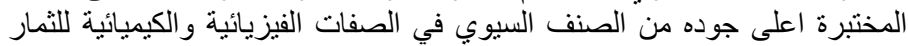

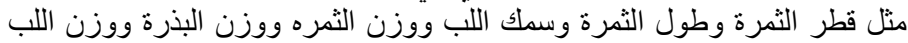

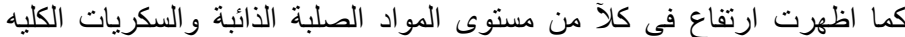
و المختزله و غير المختزله و انخفاض فى مستوى الحموضة ولئ التانينات. 